\title{
Recepcja poglądów Johna Ruskina na wychowanie w Polsce przelomu XIX i XX wieku
}

\begin{abstract}
Reception of John Ruskin's educational views in Poland at the turn of the $19^{\text {th }}$ and $20^{\text {th }}$ century

The purpose of this article is to show the reception of the educational views of John Ruskin (1819-1900) presented in Polish scientific literature at the turn of the XIX and XX century. John Ruskin was an great English writer, poet, painter and critic of art and social reality. Ruskin's oeuvre, contained in numerous writings, is the result of admiration for the world, reflection on landscapes, art and timeless values: truth, goodness and beauty; he's works are characterized by individualism, momentum, normativity, and literary style full of digression. For Ruskin, there is no clear definition of education and the educational system. Educational process itself is described in general terms. Ruskin's beliefs about art and society are connected with the issue of children's raising. The article contains numerous quotes - from the publications of Polish authors, translations and original Ruskin's works - enriching the exemplification of the problem outlined in the subject of this article. Ruskin's thoughts can be found in the foundations of progressive pedagogy and active pedagogy. For this reason, it is worth to consider the issue of the reception of educational views of Ruskin presented in Poland in years 1897-1936.
\end{abstract}

Keywords: John Ruskin, educational views, Polish scientific literature, 1897-1936

Postać i dorobek Johna Ruskina (1819-1900) stanowią zjawisko niecodzienne w kulturze nie tylko Anglii - rodzinnego kraju myśliciela - ale całej zachodniej cywilizacji. Ten wybitny pisarz, poeta, malarz, a nade wszystko krytyk sztuki i rzeczywistości społecznej za życia wzbudzał skrajne uczucia: od uwielbienia do nienawiści. Zarzucano mu moralizatorstwo, zawikłane wywody, niekonsekwencje, a nawet skłonność do 
wygłaszania arbitralnych sądów ${ }^{1}$. Niemniej wielu uważało go za przenikliwego obserwatora, idealistę o wielkiej wyobraźni, profetę, który fascynował żarliwością swoich wizji. Jego twórczość wywarła wpływ m.in. na Marcela Prousta i Mahatmę Gandhie$\mathrm{go}^{2}$. Niewątpliwie Ruskin był romantykiem, utopistą wyznającym kult piękna, przyrody i dobroci. Sprzeciwiał się wyzyskowi i złu industrialnego świata, w którym przyszło mu żyć. Usiłował słowa przekuwać w czyny, w związku z czym ponosił druzgoczące porażki i straty finansowe oraz spotykał się z ostrą krytyką. Ostatecznie swoje zaangażowanie przypłacił rozwijającą się przez lata chorobą psychosomatyczną, atakami szaleństwa i osamotnieniem ${ }^{3}$. Jednakże do historii przeszedł jako wybitny krytyk sztuki - być może najwybitniejszy - znakomity przedstawiciel ery wiktoriańskiej, błyskotliwy i odważny interpretator rzeczywistości ${ }^{4}$. Wiedza, erudycja i talenty Ruskina są przedmiotem nieustających dyskusji; w wielu krajach, nie tylko Europy, ale i świata, wciąż działają liczne towarzystwa ruskinowskie (m.in. w Anglii, Szkocji, Holandii, Stanach Zjednoczonych, Japonii, Indiach i Niemczech) $)^{5}$.

Zainteresowanie Ruskinem w Polsce wiąże się z datą jego śmierci, która nastąpiła w 1900 r. Ukazały się wtedy przekłady kilku jego dzieł ${ }^{6}$, a w ciągu następnych lat pojawiły nieliczne szersze opracowania przybliżające sylwetkę i dorobek myśliciela, m.in. broszura autorstwa Marii Bujno ${ }^{7}$. Ponadto wzmożoną koncentrację uwagi na Ruskinie w Europie pod koniec XIX w. Ignacy Matuszewski tłumaczył inspirowaniem się malarzy francuskich pracami prerafaelitów ${ }^{8}$. Wszelkie tendencje zyskujące uznanie we Francji szybko rozprzestrzeniały się na pozostałe kraje kontynentu.

Celem niniejszego artykułu jest ukazanie, jak na przełomie XIX i XX w. w piśmiennictwie polskim przedstawiano osobę Johna Ruskina oraz jego poglądy na wychowanie. W przypadku omawiania recepcji myśli Ruskina nie sposób pominąc aspektu odbioru jego samego jako wybitnej osobowości swoich czasów. Podobnie jak nie da się wypreparować z dorobku myśliciela jednoznacznej wizji systemu edukacyjnego, a także

${ }_{1}^{1}$ I. Wojnar, Wstęp, w: J. Ruskin, Sztuka. Społeczeństwo. Wychowanie. Wybór pism, Ossolineum, Wrocław 1977, s. XLIV.

${ }^{2}$ K. Jackson, The Worlds of John Ruskin, Pallas Athene Arts, Londyn 2018, s. 10.

3 Ibidem, s. 11.

${ }^{4}$ Biografię Ruskina (obejmującą dzieciństwo, relacje rodzinne i zarys przebiegu kariery) można odnaleźć we Wstepie do J. Ruskin, Sztuka. Społeczeństwo. Wychowanie, op cit.

5 M. Ulita, John Ruskin, myśliciel zapomniany?, „Wschodni Rocznik Humanistyczny” 2008, t. 5, s. 156.

6 J. Ruskin, Droga do sztuki, tłum. S. Koszutski, Warszawa 1900; idem, Sceny z podróży. Widoki natury. Wybór pism, tłum. M. Chwalibóg, Warszawa 1900; idem, O prawdziwej kobiecie (Lilie ogrodu królowej), tłum. J. Jankowski, Warszawa 1900; idem, Gałazka dzikiej oliwy. Cztery odczyty: o pracy, handlu, wojnie i przyszłości Anglii, tłum. W. Szukiewicz, Warszawa 1900; idem, Wybór pism. Malarstwo i poezja, thum. A. Lange, Warszawa 1900.

7 M. Bujno, John Ruskin i jego poglądy, Zakłady Wydawnicze „M. Arct”, Warszawa 1901.

${ }^{8}$ I. Matuszewski, Estetyka jako czynnik wychowawczo-społeczny, w: Pisma, t. 1, red. J. Muszkowski, Warszawa 1925, s. 57 (przedruk z „Gazety Polskiej” 1897). 
oddzielić przekonań dotyczących sztuki i społeczeństwa od kwestii wychowania. Artykuł zawiera liczne cytaty - z publikacji polskich autorów i tłumaczeń - oraz odniesienia do oryginalnych prac Ruskina wzbogacające egzemplifikację postawionego w temacie problemu9. Echa postulatów wytaczanych przez Ruskina odnaleźć można w założeniach amerykańskiej estetyki pragmatycznej, pedagogiki progresywistycznej, pedagogiki pracy i całym nurcie nowego wychowania. Choćby z tego powodu warto rozpatrzeć zagadnienie odbioru wychowawczych poglądów angielskiego myśliciela na gruncie polskim.

Robert de la Sizeranne wskazał rok 1860 jako przełomowy w rozwoju poglądów Ruskina $^{10}$. Rozszerzając swoje rozmyślania nad sztuką, artystami i publicznością o realia cywilizacji przemysłowej, Ruskin doszedł do wniosku, że nie sposób „wskrzesić” sztuki, nie zreformowawszy życia. Jako miłośnik przyrody - oddający jej niemal religijną cześć - nie mógł pogodzić się z degradacją środowiska naturalnego dokonywaną przez postępującą industrializację, a jako wielbiciel piękna obecnego w każdej dziedzinie życia i zwolennik chrześcijańskiej zasady wzajemnej pomocy nie akceptował ubóstwa i wyzysku klasy robotniczej. W przedmowie do polskiego wydania Gałazki dzikiej oliwy Julian Ochorowicz podkreślił, że Ruskin odrzucił wszystkie zdobycze kultury, które przynoszą tylko jednostronne korzyści, jednocześnie odbierają ludziom „zdrowie fizyczne i moralne, przygłuszają poczucie piękna i wszelkich ideałów etycznych, czyniąc człowieka tylko bezdusznym kółkiem w wielkim mechanizmie przemysłowym" "11.

W Szermierzach sztuki uspołecznionej Kazimierz Kosiński, pisząc o uwielbieniu Ruskina dla przyrody, wskazywał że miłość ta:

nie doprowadziła Ruskina do myśli i uczuć religijnych, doprowadziła go natomiast do uczuć i myśli społecznych; piękno zbyt kłóciło się z nędzą życia, podczas gdy odrodzenie człowieka mogło nastąpić tylko przez nie, tj. przez piękno uspołecznione, a zresztą miłość do rzeczy martwych musiała przejść do ludzi żywych i cierpiących. A że był Ruskin z laski

${ }^{9}$ Artykuł nie stanowi przeglądu wszystkich pism traktujących lub wzmiankujących o Ruskinie, które zostały opublikowane na przełomie XIX i XX w. w Polsce. Uwaga koncentruje się na wybranych tekstach poświęconych w głównej mierze sprawom natury społeczno-wychowawczej; zostały natomiast zmarginalizowane kwestie twórczości literackiej, pracy krytycznej (w zakresie sztuki i architektury) oraz działalności artystycznej Ruskina, a także zagadnienie politycznych interpretacji jego myśli. Zob. A. Okolski, Ruskin jako ekonomista, „Biblioteka Warszawska” 1894, t. 1, z. 2; A. Potocki, Portret i krajobraz angielski, Lwów 1907; E.N.T., Piśmiennictwo angielskie w roku 1891, „Ateneum” 1892, t. 1, z. 2; I. Matuszewski, J.R. Królowa powietrza, „Tygodnik Ilustrowany” 1901, nr 29; J. Nałęcz, O J. Ruskinie, „Głos” 1901, nr 13; J.B. Marchlewski, Sztuka stosowana, „Prawda” 1901, nr 26, 27; K. Daniłowicz-Strzelbicki, John Ruskin, „Wędrowiec” 1900, nr 5, 6; K.M. Stanisławski, Tak mówit Ruskin, „Strumień” 1900, nr 6; L. Krzywicki, Dwa prądy etyczne: Nietzsche i Ruskin, „Tygodnik Ilustrowany” 1898, nr 35-36; idem, Estetyka społeczna i Ruskin, „Gazeta Polska” 1899 , nr 86; tenże, Nowocześni humaniści angielscy, „Prawda” 1892, nr 19; L. Winiarski, John Ruskin, „Strumień” 1900, nr 6, 7; M.E. Trepka, Prerafaelici angielscy, „Ateneum” 1895, t. 3; W. Feldman, J. Ruskin, „Kraj” 1899 , nr 19; W. Jabłonowski, J. Ruskin i estetyka uwielbienia, „Głos” 1899, nr 32-33; por. A. Dawidowicz, Zygmunt Balicki o wychowaniu narodowym, „Annales UMCS, sectio K” 2003, vol. X; B. Wojnowska, Ruskinizm w Młodej Polsce, w: Porównania. Studia o kulturze modernizmu, red. R. Zimand, Warszawa 1983.

${ }^{10}$ R. de la Sizeranne, Ruskin i kult piękna, t. 2, tłum. A. Potocki, Lwów-Warszawa 1908, s. 108.

11 J. Ruskin, Gałąka dzikiej oliwy. Cztery odczyty: o pracy, handlu, wojnie i przyszłości Anglii, thum. W. Szukiewicz, Warszawa 1900, s. 9-10. 
przyrodzenia nie tylko człowiekiem marzeń i kontemplacji, ale także wybitnym człowiekiem czynu, stąd cała jego działalność w życiu płynąca z jednego źródła: miłości - miłości do piękna przyrody, sztuki, do życia, czlowieka i wrzechstworzenia ${ }^{12}$.

Poglądy Ruskina opierały się na przekonaniu, że „nie może być kultu piękna tam, gdzie nie będzie kultu życia, a nie może być kultu życia tam, gdzie ludzie mają wybladłe twarze od pracy niszczącej, twarze powleczone cieniem śmierci, wycieńczone głodem, zeszpecone chorobą"13. Uczynić życie pięknym oznaczało konieczność przebudowania go do gruntu społecznie i ekonomicznie. Piękno miało stać się treścią egzystencji każdego człowieka ${ }^{14}$. Walka Ruskina o uszlachetnienie ,wielkich mas” - jak zaznaczył Witold Rubczyński - nie ograniczała się jedynie do poprawy warunków bytowych, ale zakładała odnowienie wiary w tradycyjne ideały: prawdę, dobro i piękno ${ }^{15}$; wiary, która z czasem zaowocowałaby zwycięstwem pokojowej współpracy, miłości, szczerości i sumienności ${ }^{16}$. W swojej utopijnej koncepcji Ruskin traktował piękno jako wartość moralną, manifestującą się m.in. w sztuce ${ }^{17}$. Twierdził, że tylko w godnych warunkach bytowych, w gustownym otoczeniu, przez kontakt z naturą i sztuką, człowiek może osiągnąć zdolność świadomego odróżniania dobra od $\mathrm{zła}^{18}$. U podstaw ruskinowskiej społeczno-estetycznej koncepcji świata leżało przekonanie, że największym wrogiem piękna jest nędza ${ }^{19}$. Ruskin zakładał, że człowiek, którego podstawowe potrzeby życiowe są niezaspokojone, nie jest w stanie uświadomić sobie ani kontemplować wyższych wartości moralnych, na czele z pięknem. W książce Samuela Saengera (dodatku do „Przeglądu Tygodniowego”), przybliżającej życie i działalność Ruskina, można przeczytać, że droga myśliciela do podniesienia ogólnego stanu kultury była „wprost odwrotną jak u Schillera; nie estetyczne wychowanie rodu prowadzi do udoskonalenia moralnego" pisał Saenger - „ale etyczne wychowanie jest przedstopniem do estetycznego"20.

W swoich rozmyślaniach Ruskin nader często przeciwstawiał sobie różne wartości, np. spokojne wiejskie życie konfrontował z niezdrową rzeczywistością przeludnionych

12 K. Kosiński, Szermierze sztuki uspołecznionej (Totstoj, Morris, Ruskin), Warszawa 1928, s. 59.

13 Ibidem, s. 66-67.

${ }_{14}$ Powszechne wychowanie estetyczne według Ruskina miało polegać przede wszystkim na uszlachetnianiu tego co powszednie i codzienne, gdyż - jak pisał S. Saenger - nie ma rzeczy tak prozaicznych, aby nie mogła udzielić się im cząsteczka piękna (por. S. Saenger, John Ruskin, jego życie i działalność, Warszawa 1901, s. 51).

15 M.E. Nekanda-Trepka, Kronika londyńska, „Biblioteka Warszawska” 1900, t. 2, s. 82.

16 W. Rubczyński, Aksjologia Ruskina, „Kwartalnik Filozoficzny” 1937, t. 13, s. 148-150.

${ }_{17}$ Ruskin twierdził, że sztuka wyrasta z życia i życiu służy, dlatego też powinna stać się istotnym elementem rzeczywistości społecznej i udziałem wszystkich ludzi bez względu na status (I. Wojnar, Wstęp, op. cit., s. XXX).

${ }^{18}$ M. Ulita, John Ruskin, op. cit., s. 151.

19 R. de la Sizeranne, Ruskin i kult, op. cit., s. 135.

${ }^{20}$ S. Saenger, John Ruskin, jego życie i działalność, Warszawa 1901, s. 14. 
aglomeracji, wynędzniałego wychowanka miasta $\mathrm{z}$ dzieckiem natury ${ }^{21}$, pracę indywidualną z maszynową, etykę z „martwą" oświatą, prostotę ze zbytkiem, doskonalenie charakteru z materializmem, sztukę ze „sztuczką", wiarę z apatią, barwne ideały z szarą rzeczywistością, naturalny rytm pracy z gorączkowym postępem, „prawdziwe bogactwa” ze wszechwładnym pieniądzem. Choć formułując swoje poglądy, nieraz popadał w patetyczny ton, jego wzniosłym ideom nie sposób odmówić słuszności. Ochorowicz pisał:

Ruskin idee szlachetności rycerskiej wprowadza do przemysłu i handlu, tworząc wzór kupca, któryby odpowiadał dawnym wzorom rycerza, w zastosowaniu do zmienionych warunków bytu [...]. Ruskin wprowadza kult piękna do wszystkich dziedzin życia, a etykę do ekonomii politycznej. Takie jest najkrótsze określenie jego stanowiska, jego wiary z młodzieńczym zapałem krzewionej ${ }^{22}$.

W polskim piśmiennictwie omawianego okresu Ruskina przedstawiano jako człowieka czynu, bojownika ${ }^{23}$, bohatera idei ${ }^{24}$, marzyciela piękna ${ }^{25}$, a nawet geniusza ${ }^{26}$; pisano, że był otoczony nimbem apostoła i propagatora ${ }^{27}$, że „wywarł wpływ wprost wyją̧tkowy i, jak na dziś, wymierzyć się niedający na rozległe dziedziny, duchowego i społecznego życia swoich ziomków"28; podkreślano, że przeznaczył prawie cały olbrzymi majątek na zakładanie instytucji i muzeów otwartych dla wszystkich ludzi; że wojował słowem, piórem i czynem ${ }^{29}$. Jednak ocena działalności Ruskina nie była oceną bezkrytyczną. Choć owa krytyka sprowadzała się raczej do przytaczania zastrzeżeń kierowanych pod adresem Ruskina przez jego rodaków, przy jednoczesnym ich kwestionowaniu. Władysław Jabłonowski pisał: „Wytykano Ruskinowi sprzeczności jego życia i pism, postępków i myśli [...]. Widziano niestałość tam, gdzie był tylko stały entuzjazm dla wielu przedmiotów, paradoksalność i samowolę - tam gdzie była tylko wielka szczerość" 30 .

Rubczyński, odnosząc się do wniosków wyprowadzonych przez R. de la Sizeranne'a, stwierdził, że:

U Ruskina nie należy szukać ani konsekwencji, ani głębszego uzasadnienia pomysłów, ani nawet silnego i szczerego przekonania o prawdziwości tego, co twierdzi, gdyż w oczach autora

\footnotetext{
${ }^{21}$ M. Bujno, John Ruskin, op. cit., s. 24-25.

22 J. Ruskin, Gałazka dzikiej oliwy, op. cit., s. 9-10.

${ }^{23}$ W. Szukiewicz, John Ruskin (1819-1900), ,Tygodnik Ilustrowany”1900, nr 5, s. 87.

${ }^{24}$ Idem, Apostoł piękna, „Biblioteka Warszawska” 1900, t. 2, s. 141.

${ }^{25}$ K. Kosiński, Szermierze sztuki, op. cit., s. 61.

26 A. Lange, Studya i wrażenia, Warszawa 1900, s. 151-177.

27 W. Rubczyński, Aksjologia Ruskina, op. cit., s. 136.

${ }^{28}$ Idem, John Ruskin. Studia nad powiązaniem i uzasadnieniem jego głównych pomysłów, cz. 1, Kraków 1905, s. 3.

${ }^{29}$ W. Jabłonowski, Wśród obcych, Lwów 1905, s. 217.

30 Ibidem, s. 218.
} 
jest to przede wszystkim improwizator, mówiący i piszący pod dyktatem świeżych bardzo i żywych, ale chwilowych, przelotnych wrażeń, wydobywający z nich nieraz olśniewająco jasne, bystre i głębokie intuicje stanów duszy i warunków upodobań estetycznych, jednak bez dbałości o jakikolwiek system, powiązanie lub rozwinięcie swoich zdobyczy ${ }^{31}$.

Ochorowicz zaznaczył, że w pismach Ruskina pojawiają się „dziwactwa i neoromantyczne fantazje”, za którymi „ciągnie falanga narwańców, dużo protestujących, ale mało wiedzących czego chcą" "32. Co i tak w ostatecznym rozrachunku, zdaniem J. Ochorowicza, nie umniejszało rangi ruskinowskich postulatów ${ }^{33}$. Wojciech Szukiewicz w artykule zamieszczonym w „Tygodniku Ilustrowanym” stwierdził, że w przypadku Ruskina wielka przenikliwość i skromność łączyła się z pewnego rodzaju naiwnością, zjednującą mu słuchaczy w różnych środowiskach ${ }^{34}$. Również M. Bujno zwróciła uwagę na bogaty, literacki i pełen dygresji, przez co niełatwy w odbiorze styl Ruskina oraz liczne sprzeczności pojawiające się w jego tekstach ${ }^{35}$.

Dorobek Ruskina trudno nazwać filozofią nie tylko z powodu niekonsekwencji, ale także dlatego, że język, którego używał, był poetycki, zbytnio emocjonalny, właściwie pozbawiony pojęć o stałych znaczeniach. Ponadto Ruskin publikował bardzo intensywnie, a poszczególne wydawnictwa stanowiły amalgamat różnych spostrzeżeń i przemyśleń; nie były to - w większości przypadków - dzieła poświęcone jednemu problemowi. Stąd być może przewaga w polskim piśmiennictwie opinii raczej ogólnych, oddających pewien generalny zamysł Ruskina, nad szczegółową analizą jego poglądów o wychowaniu.

Większość swoich przemyśleń pedagogicznych Ruskin zawarł w jednym z listów zamieszczonych w Time and Tide ${ }^{36}$. Pojawiły się w nim tezy, które można uznać za główne idee wychowawcze Ruskina ${ }^{37}$. Według myśliciela to od dbałości o zdrowie fizyczne (również piękne ciało) oraz od wzbudzenia podziwu, entuzjazmu i współczucia

31 W. Rubczyński, John Ruskin, op. cit., s. 10.

32 J. Ruskin, Gałazka dzikiej oliwy, op. cit., s. 9.

33 Ibidem, s. 9.

34 W. Szukiewicz, John Ruskin, op. cit., s. 87.

35 „Styl dzieł Ruskina po większej części kaznodziejski, moralizatorski, bywa często przeplatany sarkazmem i goryczą; przechodzi w rzewny liryzm i cieniuje z dokładnością najsubtelniejszego pędzla, to rzuca grube ledwie naszkicowane kontury; rozlewa się w potoku słów dźwięcznych, harmonijnych, w okresach potoczystych, zaokrąglonych, to pada deszczem drobnych zwrotów, topiąc w szczegółach myśl przewodnią; to posuwa się naprzód spokojnie, równo, to błyśnie paradoksem, przekształcającym się w dalszym ciągu w nieskończone współczucie dla niedoli bliźniego. W jednym miejscu np. pisze, że dewizą szlachetnego życia powinny być słowa: ,jedźmy, pijmy, bo jutro pomrzemy”, a gdy zdumiony czytelnik nie dowierza, aby to mogły być słowa wielkiego myśliciela, ten zaraz dodaje: ,„ale jedźmy i pijmy wszyscy, nie zaś niektórzy tylko, nakłaniając wszystkich do wstrzemięźliwości” (M. Bujno, John Ruskin, op. cit., s. 34-35).

36 Time and Tide to książkowe wydanie zbioru 25 listów napisanych przez Ruskina do Thomasa Dixona robotnika zajmującego się zagadnieniami ekonomicznymi. Po raz pierwszy wydawnictwo ukazało się w $1867 \mathrm{r}$. Listy zawierają ostrą krytykę życia społecznego oraz elementy programu utopijnego Ruskina.

37 Por. J. Ruskin, Morning in Florence and Time and Tide, New York 1889, s. 69. 
powinno rozpoczynać się wszelkie wychowanie ${ }^{38}$. „Cześć i szacunek z jednej strony, a współczujące serce z drugiej, powinny stanowić podstawę wychowania moralnego"39. Jabłonowski spointował poglądy myśliciela (podając najprawdopodobniej za R. de la Sizeranne'em ${ }^{40}$ ) w następujących słowach:

Zaprzątamy się wykształceniem dzieci [...], ale bynajmniej nie ich wychowaniem, gdyż wychowywać dziecko - nie znaczy to wcale nauczyć je czegoś, czego przedtem nie wiedziało, lecz zrobić zeń kogoś, kim pierwej nie było. Budzić uczucia zachwytu i uwielbienia można wszystkim, przedmiot nie odgrywa tu główniej roli. Niech dziecko podziwia kamienie i warzywa, jeśli nie mamy innych bogów godnych jego uwielbienia, lecz przede wszystkim niech umie uwielbiać ${ }^{41}$.

Szukiewicz określił Ruskina mianem gorącego orędownika wszechstronnego rozwoju, dostrzegając w nim propagatora nowoczesnego wychowania; wychowania, którego celem, obok rozwoju ciała i kształcenia stosownych umiejętności, był rozwój duszy ${ }^{42}$.

W 1903 r. ukazała się książka Janiny Mortkowiczowej $O$ wychowaniu estetycz$n e m^{43}$. Było to pierwsze polskie, usystematyzowane opracowanie poświęcone tej tematyce. Autorka wielokrotnie powoływała się w nim na poglądy Ruskina ${ }^{44}$, włączając jego myśli w koncept „reformy estetyczno-pedagogicznej”45. Mortkowiczowa

${ }^{38}$ Ruskin pisał: „wychowanie zacząć należy od nauki „,zasad, od których zależy zdrowie, i od ćwiczeń fizycznych, zalecanych ze względu na nie" [...]. Wraz z wychowaniem sprawności fizycznej należy rozwijać dwa przymioty duchowe: szacunek i współczucie dla drugiego człowieka. Nie można - rzecz jasna - tych cnót się nauczyć w dosłownym tego słowa znaczeniu. Chociaż są to cechy dziedziczne każdej zdrowo urodzonej jednostki, należy je rozwijać, podobnie jak tężyzna ciała wymaga rozmyślnego, stałego ćwiczenia. Nigdy nie mogłem pojąć, dlaczego Goethe (w swoim projekcie wychowania zamieszczonego w utworze «Wilhelm Meister») powiada, iż postawa szacunku nie jest rzeczą wrodzoną, lecz należy ją dziecku zaszczepić. Według mnie jest to do tego stopnia nieodrodną cechą psychiki, że ludzie nie mając innego obiektu szacunku, będą czcić szaleńca bądź kamień, bądź roślinę. Wychowanie w tej dziedzinie polega na uczynieniu przedmiotem szacunku właściwych osób i rzeczy" (J. Ruskin, Sztuka, op. cit., s. 283-284).

39 J. Ruskin, Sztuka, op. cit., Wrocław 1977, s. 284.

40 Por. R. de la Sizeranne, op. cit., s. 145.

41 W. Jabłonowski, Wśród obcych, op. cit., s. 227.

42 W. Szukiewicz, John Ruskin, op. cit., s. 87.

43 J. Mortkowiczowa, O wychowaniu estetycznem, Warszawa 1903.

${ }^{44}$ Ibidem, s. 2, 5, 9, 18, 20, 29, 45-46, 50, 58, 66, 71; por. A. Boguszewska, Zamierzenia wychowania estetycznego $w$ zakresie plastyki wobec dziecka $w$ Polsce lat dwudziestych XX wieku, „Annales UMCS, sectio L" 2004, vol. II, s. 228; A. Lisiecka, Założenia realizacji przedmiotów artystycznych w polskim szkolnictwie powszechnym w latach 1918-1939, Wydawnictwo UMCS, Lublin 2020, s. 143; K. Pankowska, Rozwój polskiej teorii wychowania estetycznego - prekursorzy i twórcy, „Kwartalnik Pedagogiczny” 2017, nr 4(246), s. 43-44.

${ }_{45}$ Por. ibidem, s. 12; o wpływie poglądów Ruskina na polski ruch estetyczno-pedagogiczny pisały m.in. Katarzyna Dormus i Mirosława Zalewska-Pawlak; zob. K. Dormus, Rozwój form wychowania estetycznego i nauczania rysunku w Krakowie w latach 1850-1914, Polska Akademia Nauk, Warszawa 1998, s. 75; M. Zalewska-Pawlak, Rola sztuki w wychowaniu. Polska tradycja pedagogiczna, Wydawnictwo Uniwersytetu Łódzkiego, Łódź 2001, s. 28. 
podkreśliła związek moralności z estetyką ${ }^{46}$ oraz wpływ codziennego otoczenia dziecka na rozwój jego wrażliwościi ${ }^{47}$. Podążając dalej za Ruskinem, wskazała na przyrodę jako nieskończone źródła piękna i inspiracji dla dziecięcej twórczości ${ }^{48}$. W swoich reformatorskich założeniach autorka sprzeciwiła się schematyzmowi w nauczaniu rysunku, w jego miejsce wprowadzając swobodną zabawę artystyczną, dostarczającą dzieciom przyjemności ${ }^{49}$.

Jedyną publikacją ${ }^{50}$, a właściwie serią publikacji, w której omówiono bardziej szczegółowo poglądy pedagogiczne Ruskina, jest cykl trzech krótkich artykułów Stanisława Posnera opublikowanych na łamach tygodnika „Prawda” w 1900 r. $^{51}$. W pierwszym tekście S. Posner nakreślił syntetyczną biografię myśliciela, wskazując na jego zaangażowanie społeczne oraz próby szerzenia oświaty wśród klas pracujących i wynikające z nich „nieprzyjemności i trudności” ${ }^{2}$. W drugim artykule tak pisał o Ruskinie:

To nie jest żaden autor kilkunastu przyczynków do teorii kojarzeń i komórki nerwowej, żaden zwyczajny albo nadzwyczajny profesor niemiecki. Należy on do tych dzisiaj zaginionych gatunków „rodzaju filozofów”, co to pod platanami i po gajach oliwnych Aten przechadzając się, rozprawiali mądrze i dowcipnie, niekiedy wzniośle pod względem etycznym, doskonale pod względem logicznym - o wszystkim i o niczym, o wszelkich sprawach boskich i ludz$\mathrm{kich}^{53}$.

Dalej S. Posner zaprezentował przemyślenia Ruskina na temat systemu edukacji; pokreślił rolę państwa w wychowaniu (to właśnie w sferze obowiązków państwa leżało zadbanie o dobrostan wszystkich dzieci - o mieszkanie, ubiór, wartościowe posiłki i opiekę aż do wieku dojrzałości) oraz omówił warunki, w których miało przebiegać kształcenie; mianowicie: szkoły należało budować w miejscach nieskażonych przez przemysł, na dużych przestrzeniach ziemi, gdzie uprawiać można jazdę konną, wyścigi piesze oraz ćwiczyć się w taktyce wojskowej - defensywnej i ofensywnej. Dzieciom należało wpajać szacunek ${ }^{54} \mathrm{i}$ współczucie dla drugiego człowieka oraz zaszczepiać w nich uczciwość i prawdomówność.

\footnotetext{
46 Ibidem, s. 2.

${ }^{47}$ Por. ibidem, s. 56-68.

48 Por. ibidem, s. 29.

49 Por. ibidem, s. 36-30.

${ }^{50}$ Podczas kwerendy autorka nie natrafiła na inne źródła, które traktowałyby szerzej o poglądach wychowawczych Ruskina, co nie oznacza, że takowe nie istnieją - w tym wypadku autorka prosi o wiadomość na adres: a.lisiecka@poczta.umcs.lublin.pl lub/i lisiecka91@o2.pl.

51 S. Posner, John Ruskin, „Prawda” 1900, nr 4; idem, John Ruskin, „Prawda” 1900, nr 5; idem, John Ruskin, „Prawda” 1900, nr 6.

52 Idem, John Ruskin, „Prawda” 1900, nr 4, s. 43-44.

53 Idem, John Ruskin, „Prawda” 1900, nr 5, s. 55.

${ }_{54}$ Posner nie wspomina o roli Mistrzów, których uczniowie mogliby kochać i szanować, a nadmienia o tym Ruskin w Time and Tide.
} 
Wreszcie przechodząc do kształcenia umysłu, należy uczyć historii, przyrodoznawstwa i matematyki, a przede wszystkim języka ojczystego. Dzieci, które życie swe spędzić mają w mieście, powinny, o ile da się to pogodzić z ich skłonnościami, uczyć się matematyki i sztuk pięknych; dzieci przeznaczone do zajęć wiejskich, winny poznawać historię naturalną ptaków, owadów i roślin, a jednocześnie uczyć się uprawiać ogród szkolny ${ }^{55}$.

Ruskin wymienił jeszcze trzecią grupę dzieci, obok wiejskich i miejskich - o czym S. Posner nie wspomniał - a mianowicie dzieci żyjące na wybrzeżu, które w przyszłości mogły zostać marynarzami. Te powinny uczyć się geografii fizycznej, astronomii i historii naturalnej, gatunków ryb i ptaków morskich ${ }^{56}$. Tym samym Ruskin zaproponował swego rodzaju profile kształcenia uwarunkowane miejscem zamieszkania, potrzebami życia i pochodzeniem.

Posner również wskazał na sprzeczności obecne w poglądach wybitnego estety, które w pierwszym momencie mogłyby uchodzić za różnice nie do pogodzenia. Pisał:

Dziwnym to się wydać może, iż Ruskin jest obrońcą feudalizmu. Każdy człowiek społeczności ludzkiej powinien zajmować ściśle określone stanowisko; różnice są wieczne i mądre. Dzieci robotników prostych, niewykształconych, zupełnie sprawiedliwie przeznaczone są do wykonywania zwyczajnej, prostej pracy, dla dzieci rzemieślników z warunków dziedziczności (talentu, usposobień itp.) i środowiska wypływa możliwość i konieczność pracy w zakresie zajęć rodziców; i zupełnie taka sama ciągłość w działalności życiowej powinna obowiązywać klasy wyższe, rządzące ${ }^{57}$.

Jednym z fascynujących paradoksów w życiu Ruskina - według Kevina Jacksona - jest to, że mimo postępowych poglądów był on zdeklarowanym torysem: wyznawcą królów i królowych, hierarchii i posłuszeństwa, pobożności i rycerskości ${ }^{58}$.

55 Ibidem, s. 56.

56 J. Ruskin, op. cit., s. 286.

57 S. Posner, John Ruskin, „Prawda” 1900, nr 6, s. 68.

${ }^{58}$ W Time and Tide (por. J. Ruskin, Morning in Florence, op. cit., s. 67) Ruskin pisał: „Tu więc tkwi prawdziwa przyczyna naszych dotychczasowych niepowodzeń na polu wychowania - zarówno koncepcji pochodzących z górnych warstw społecznych, jak z jego dołów. Jest nią brak bezinteresownego działania, mającego na celu wychowanie jako takie. Domaganie się wykształcenia przez warstwy niższe pochodzi z ich mniemania, iż z chwilą gdy je osiągną, staną się warstwą wyższą. Istnieje dziwny pogląd wśród szerokich mas (podzielany dzisiaj przez wszystkich znanych pedagogów i ekonomistów, których tu mamy prawo włączyć do tak zwanych „mas”), że każdy człowiek może awansować do elity społecznej, a w każdym razie, iż powszechny proces wspinania się w górę, proces, w którym każdy ostatecznie osiągnie szczyt - odpowiada ustrojowi wymarzonemu przez utopistów. Ludziom tym wydaje się, że wystarczy zapewnić każdemu młodemu chłopcu należyte wykształcenie, by zdobył pozycję pozwalającą na rozjeżdżanie się własnym powozem (nie zastanowiono się tylko nad tym, w jaki sposób zaspokoić zapotrzebowanie na stangretów i lokai). A ja powiadam stanowczo opierając się na tym, czego jestem absolutnie pewien - iż lepiej, aby człowiek nie umiał pisać i czytać, niżby miał otrzymywać tego rodzaju wykształcenie. Pierwszym warunkiem użyteczności wychowania jest jego właściwe założenie: należy jasno zdawać sobie sprawę, iż nie ma ono być środkiem do wspinania się w górę po szczeblach życiowej kariery, lecz zabezpieczeniem dobrego życia na pozycji dotychczas zajmowanej” (J. Ruskin, Sztuka, op. cit., s. 282). 
Tymczasem jego najzagorzalsi uczniowie - na czele z Williamem Morrisem - często nazywali siebie socjalistami ${ }^{59}$. Niemniej Ruskin stał na stanowisku, że powszechna edukacja musi być zorganizowana w taki sposób, aby przynosiła korzyści dzieciom pochodzącym ze wszystkich warstw społecznych. „Każde dziecko urodzone na tej wyspie, bez względu na swoją przynależność klasową, musi podlegać prawnemu obowiązkowi kształcenia w zakresie ogólnych podstaw ludzkiej wiedzy i otrzymać chrzest $[\ldots]]^{\prime 60}$.

W pismach Ruskina odnaleźć można liczne fragmenty świadczące o jego konserwatywnych poglądach ${ }^{61}$, należy jednak pamiętać, że myśliciel zaciekle bronił godności każdego człowieka, sprzeciwiał się wyzyskowi i pracy, która degenerowała ludzkie ciało i umysł. Rubczyński zaznaczył, że Ruskin żądał

pomnożenia liczby zajęć takich, przy których trud łączyłby się o ile możności z zadowoleniem potrzeb estetycznych i które by mechanizmem swym nie zabijały myśli, a wykonywane wśród warunków higienicznych i w jak najczęstszym bezpośrednim zetknięciu z naturą, wyrabiały duchową pogodę, uczyły przestawać na skromnych warunkach i potrzebach, znajdować główną radość w samym przedmiocie pracy, w jego tworzeniu i kształtowaniu, a nie w dalszych, ubocznych do niego przywiązanych celach lub widokach ${ }^{62}$.

W trzecim artykule S. Posner poruszył także kwestię stosunku Ruskina do wychowania i pozycji społecznej kobiet. W nieco szyderczym tonie przytoczył opinie myśliciela o wyraźnym podziale obowiązków na kobiece i męskie. Rolą kobiety polegała na pilnowaniu ogniska domowego, byciu matką, gospodynią, nad wyraz skromną i pokorną władczynią domu, zaniechującą wszelkiej aktywności w dziedzinie przemysłu, gdyż takowa byłaby niczym więcej jak próbą współzawodnictwa z płcią męską. Mężczyzna to natomiast wynalazca, wojownik, obrońca, zdobywca. Kobieta, obdarzona przyrodzoną cierpliwością i zdolnością do utrzymania ładu i podejmowania decyzji, stworzona była do rządzenia (lub może trafniej: rozporządzania), a nie do twórczości. Posner podał za Ruskinem: „U świętego ogniska domowego, z dala zabezpieczona od zgiełku, egoizmu i brutalności świata zewnętrznego, niechaj panuje jako źródło i oś porządku, jako pocieszycielka w strapieniu, jako zwierciadło piękna" ${ }^{63}$. Ażeby sprostać stawianym przed nią zadaniom, kobieta musiała odebrać stosowne wykształcenie; obejmowało ono: ćwiczenia fizyczne gwarantujące dobre zdrowie i urodę, zajęcia

59 K. Jackson, op. cit., s. 10.

${ }^{60}$ J. Ruskin, Sztuka, op. cit., s. 282

${ }^{61}$ Należy także podkreślić, że literacki rozmach Ruskina sprawiał, że niektóre tezy przez niego stawiane wydawały się przesadne; np. w Time and Tide, kiedy radził, aby unikać zasiewania w duszy dziecka niepewności, nie uczyć wychowanka rzeczy, których nauczyciel sam nie jest pewien, pojawiło się następujące zdanie: Better that it should be ignorant of a thousand truths, than have consecrated in its heart a single lie (J. Ruskin, Morning in Florence, op. cit., s. 69).

62 W. Rubczyński, John Ruski, op. cit., s. 14.

${ }^{63}$ S. Posner, John Ruskin, „Prawda” 1900, nr 6, s. 69. 
praktyczne oraz lekturę poszerzającą krąg zainteresowań (ukierunkowanych głównie na sztuki piękne) ${ }^{64}$.

W dalszej części tekstu S. Posner uszczypliwie zauważył, że Ruskin w swoich wizjach nie zapomniał także o wyznaczeniu kobietom stosownego obszaru działalności społecznej; nie mogła być nim w żadnym wypadku polityka, ale jedynie pomoc słabszym i potrzebującym, realizująca ideę miłosierdzia. Trudno nie się zgodzić z krytycznym tonem S. Posnera. W istocie Ruskin widział kobietę jako osobę w gruncie rzeczy poddaną, pasywną, której edukacja (dla jej własnego dobra) powinna być ograniczona ,żeńską naturą” - moralnością, wrażliwością, predyspozycjami intelektualnymi. Jednakże S. Posner pominął kilka faktów stawiających myśliciela w nieco lepszym świetle. W O prawdziwej kobiecie Ruskin wyraźnie podkreślił równą godność kobiety i mężczyzny ${ }^{65}$, wskazał na potrzebę społecznej oraz fizycznej aktywności kobiet $^{66}$, co było rzeczą niespotykaną wśród klas wyższych, a także położył wyraźny nacisk na rzeczywiste rozwijanie potencjału intelektualnego dziewcząt. Zwrócił się do ludzi swojej epoki:

Wychowujecie córki wasze, jakby one istniały tylko po to, żeby być sprzętami do ozdoby salonu i następnie żalicie się na ich lekkomyślność; dajcież więc im te prawa, jakie dajecie chłopcom; powołajcie w nich te same uczucia męstwa i cnoty; zaszczepcie w nich to samo przekonanie, że prawość i męstwo są to filary ich istoty ${ }^{67}$.

${ }^{64}$ W O prawdziwej kobiecie (Sesame and lilies) Ruskin pisał: „Winiliście więc najpierw ukształtować jej rozwój fizyczny, następnie, o ile pozwolą siły, które zdobędzie, wypełnić jej umysł wszystką wiedzą, wszystkimi myślami, które mogą przyczynić się do umocnienia przyrodzonych instynktów jej słuszności i do wycieniowania przyrodzonego poczucia jej miłości. Trzeba jej dać poznać wszystką wiedzę, która uczyniłaby ją zdolną zrozumieć trud mężczyzny i współdziałać z nim. Nie trzeba jednak zaszczepiać w niej wiedzy w większej mierze nad tę, która dotyczy uczuć i sądów jedynie, właśnie tak, jak gdyby całkowite poznanie nie miało być nigdy jej sprawą. Nie jest rzeczą żadnej wagi (jak gdyby to miało stanowić cel jej dumy lub doskonałości!), czy będzie posiadała jeden język, czy więcej, lecz jest rzeczą wielkiej wagi, żeby potrafiła wszystką uprzejmość swoją oświadczyć cudzoziemcowi i pojąć słodycz języka obcokrajowca. Nie jest rzeczą całkiem potrzebną ani dla jej wartości, ani dla jej godności osobistej, żeby wiedzę jakąś umiała na wylot, lecz jest rzeczą nieskończenie potrzebną, żeby była wychowaną w regule myśli czystej, poprawnej, żeby rozumiała, czym są prawa przyrodzone, jak są strojne i nieprzełamane. Pragnąłbym, żeby choć jedną ścieżką poszukiwań naukowych dotarła do progu tej Doliny Pokory, na którą wstępują najdzielniejsi i najmądrzejsi, sami siebie mający wiecznie za dzieci, zbierające kamyki u brzegów bezgranicznych! Jest rzeczą całkiem błahej wartości, ile będzie umiała pozycji miast, dat wypadków i nazwisk sławnych osobistości; cel wychowania nie polega na tym, żeby kobietę przemienić w dykcjonarz, lecz jest rzeczą głębokiego znaczenia, żeby ją nauczono całą istotą wniknąć w historię, którą odczytuje; całym swoim życiem odmalować przebieg wypadków - przy pomocy świetnej wyobraźni, odczuć i pochwycić tą przędzą delikatną instynktu wszystką patetyczność warunków, dramatyczność sytuacji, które często historyk zaciemnia wskutek rozumowań lub rozłącza wskutek układu. Zadaniem jej jest zdążać śladami przesłoniętej słuszności wyroków Bożych i dostrzegać poprzez mroki fatalną nitkę ognistą, która wiąże występek z karą zasłużoną" (J. Ruskin, O prawdziwej kobiecie (Lilie ogrodu królowej), tłum. J. Jankowski, Warszawa 1900, s. 38-41).

65 J. Ruskin, O prawdziwej kobiecie, op. cit., s. 7.

${ }^{66}$ Ruskin zalecał pracę w ogrodzie dziewczętom z wyższych klas społecznych.

67 Ibidem s. 52. 
Warto przypomnieć, że pierwsze wydanie Sesame and lilies ukazało się w $1865 \mathrm{r}$. Zatem na tle wiktoriańskiej rzeczywistości dziewiętnastowiecznej Anglii, gdzie kobieta była stworzeniem bezwzględnie podporządkowanym, efemerycznym, blado upudrowanym, oderwanym od własnego ciała, wciśniętym w sztywne gorsety i ramy społecznych konwenansów $w^{68}$, poglądy Ruskina na kwestię kobiecą wypada uznać - mimo wszystko za postępowe.

Chociaż John Ruskin nie stworzył konkretnego modelu edukacyjnego ani też nie zajmował się w szczególności wychowaniem, to reminiscencje jego poglądów pedagogicznych znalazły swoje odbicie w polskim piśmiennictwie omawianego okresu. Najczęściej wątki związane z wychowaniem pojawiały się przy prezentowaniu całokształtu dorobku angielskiego myśliciela oraz w tłumaczeniach; zdecydowanie rzadziej stanowiły odrębny przedmiot analiz. Największe zainteresowanie Ruskinem przypadło na przełom wieków i wiązało się ze śmiercią tego „największego filozofa epoki”, za którego go przecież uważano, choć jego teorie tak bardzo odbiegały od standardów filozofii akademickiej. Dorobek Ruskina, uwieczniony w licznych pismach, jest rezultatem zachwytu nad światem, refleksji nad krajobrazami, sztuką oraz ponadczasowymi wartościami: prawdą, dobrem i pięknem; cechuje go indywidualizm, rozmach, normatywność, literacki styl pełen dygresji. U Ruskina nie występuje jednoznaczna definicja wychowania; sam proces kształcenia opisany jest ogólnikowo; jednakże główne idee pedagogiczne wydają się celne i aktualne. Trudno nie zgodzić się z Ruskinem, że gdy miłość stanie się podstawą wychowania, rozwinie się w dzieciach entuzjazm dla tego, co wielkie, piękne i szlachetne; że wszelka nauka jest o tyle pożyteczna, o ile pogłębia w istocie ludzkiej miłość do życia. W swoich traktatach ekonomiczno-społecznych i wychowawczych Ruskin uzasadniał istnienie trzech nieodzownych potrzeb duchowych: podziwu, miłości i nadziei oraz analogicznych i równoległych trzech potrzeb fizycznych: mieszkania, pożywienia i ubioru, których zaspokojenie powinno obejmować wszystkich ludzi. W sprawiedliwości społecznej umożliwiającej świadomą egzystencję - upatrywał drogi do powszechnego szczęścia. Ruskin kochał piękno estetyczne i pragnął, aby każdy człowiek mógł dzielić z nim tę miłość.

\section{Bibliografia}

Boguszewska A., Zamierzenia wychowania estetycznego w zakresie plastyki wobec dziecka w Polsce lat dwudziestych XX wieku, „Annales UMCS, sectio L” 2004, vol. II, s. 227-240.

Bujno M., John Ruskin i jego poglady, Warszawa 1901.

Daniłowicz-Strzelbicki K., John Ruskin, „Wędrowiec” 1900, nr 5, 6.

${ }^{68}$ Por. A. Gromkowska-Melosik, Ciało, moda i tożsamość kobiety epoki wiktoriańskiej - dyskursy piękna i przemocy, „Kultura - Społeczeństwo - Edukacja” 2012, nr 2, s. 17-30. 
Dawidowicz A., Zygmunt Balicki o wychowaniu narodowym, „Annales UMCS, sectio K” 2003, vol. X, s. 159-172.

Dormus K., Rozwój form wychowania estetycznego i nauczania rysunku w Krakowie w latach 1850-1914, Warszawa 1998.

E.N.T., Piśmiennictwo angielskie w roku 1891, „Ateneum” 1892, t. 1, z. 2.

Feldman W., J. Ruskin, „Kraj” 1899, nr 19.

Gromkowska-Melosik A., Ciało, moda i tożsamość kobiety epoki wiktoriańskiej - dyskursy piękna i przemocy, „Kultura - Społeczeństwo - Edukacja” 2012, nr 2.

Jabłonowski W., J. Ruskin i estetyka uwielbienia, „Głos” 1899, nr 32-33.

Jabłonowski W., Wśród obcych, Lwów 1905.

Jackson K., The worlds of John Ruskin, London 2018.

Kosiński K., Szermierze sztuki uspołecznionej (Totstoj, Morris, Ruskin), Warszawa 1928.

Krzywicki L., Dwa prądy etyczne: Nietzsche i Ruskin, „Tygodnik Ilustrowany” 1898, nr 35-36.

Krzywicki L., Estetyka społeczna i Ruskin, „Gazeta Polska” 1899, nr 86.

Krzywicki L., Nowocześni humaniści angielscy, „Prawda” 1892, nr 19.

Lange A., Studya i wrażenia, Warszawa 1900.

Lisiecka A., Założenia realizacji przedmiotów artystycznych $w$ polskim szkolnictwie powszechnym w latach 1918-1939, Lublin 2020.

Marchlewski J.B., Sztuka stosowana, „Prawda” 1901, nr 26, 27.

Matuszewski I., Estetyka jako czynnik wychowawczo-spoleczny, w: Pisma, red. J. Muszkowski, t. I, Warszawa 1925.

Matuszewski I., J.R. Królowa powietrza, „Tygodnik Ilustrowany” 1901, nr 29.

Mortkowiczowa J., O wychowaniu estetycznem, Warszawa 1903.

Nałęcz J., O J. Ruskinie, „Głos” 1901, nr 13.

Nekanda-Trepka M.E., Kronika londyńska, „Biblioteka Warszawska” 1900, t. 2.

Okolski A., Ruskin jako ekonomista, „Biblioteka Warszawska” 1894, t. 1, z. 2.

Pankowska K., Rozwój polskiej teorii wychowania estetycznego - prekursorzy i twórcy, „Kwartalnik Pedagogiczny" 2017, nr 4(246), s. 41-55.

Posner S., John Ruskin, „Prawda” 1900, nr 4.

Posner S., John Ruskin, „Prawda” 1900, nr 5.

Posner S., John Ruskin, „Prawda” 1900, nr 6.

Potocki A., Portret i krajobraz angielski, Lwów 1907.

Rubczyński W., Aksjologia Ruskina, „Kwartalnik Filozoficzny” 1937, t. VIII.

Rubczyński W., John Ruskin. Studia nad powiazaniem i uzasadnieniem jego głównych pomystów, cz.1, Kraków 1905.

Ruskin J., Droga do sztuki, thum. S. Koszutski, Warszawa 1900.

Ruskin J., Gałazka dzikiej oliwy. Cztery odczyty: o pracy, handlu, wojnie i przyszłości Anglii, thum. W. Szukiewicz, Warszawa 1900.

Ruskin J., Morning in Florence and Time and Tide, New York 1889.

Ruskin J., O prawdziwej kobiecie (Lilie ogrodu królowej), tłum. J. Jankowski, Warszawa 1900.

Ruskin J., Sceny z podróży. Widoki natury. Wybór pism, tłum. M. Chwalibóg, Warszawa 1900.

Ruskin J., Sztuka. Społeczeństwo. Wychowanie. Wybór pism, Wrocław 1977.

Ruskin J., Wybór pism. Malarstwo i poezja, thum. A. Lange, Warszawa 1900.

Saenger S., John Ruskin, jego życie i działalność, Warszawa 1901.

Sizeranne R., Ruskin i kult piękna, t. II, tłum. A. Potocki, Lwów-Warszawa 1908.

Stanisławski K.M., Tak mówił Ruskin, „Strumień” 1900, nr 6.

Szukiewicz W., Apostot piękna, „Biblioteka Warszawska” 1900, t. 2.

Szukiewicz W., John Ruskin (1819-1900), „Tygodnik Ilustrowany” 1900, nr 5. 
Trepka M.E., Prerafaelici angielscy, „Ateneum” 1895, t. 3.

Ulita M., John Ruskin, myśliciel zapomniany?, „Wschodni Rocznik Humanistyczny” 2008, t. 5, s. $143-158$.

Winiarski L., John Ruskin, „Strumień” 1900, nr 6, 7.

Wojnar I., Wstęp, w: Ruskin J., Sztuka. Społeczeństwo. Wychowanie. Wybór pism, Wrocław 1977.

Wojnowska B., Ruskinizm w Młodej Polsce, w: Porównania. Studia o kulturze modernizmu, red. R. Zimand, Warszawa 1983.

Zalewska-Pawlak M., Rola sztuki w wychowaniu. Polska tradycja pedagogiczna, Łódź 2001. 